\title{
The Utilization of Pentoses and Pentitols by Different Biotypes of Salmonella typhimurium
}

\author{
By DAVID C. OLD \\ Bacteriology Department, University of Dundee, Dundee $D D_{2}$ I $U B$
}

(Received 30 December 1976; revised I4 March 1977)

INTRODUCTION

Biotyping is useful for differentiating types in Salmonella typhimurium. Duguid et al. (1975) used a two-tier scheme to classify 2030 S. typhimurium strains from different countries and sources into 19 of 32 potential primary biotypes and into 144 full biotypes. One advantage of their system is that it allows the incorporation of further tests at the secondary level. Thus, new tests and substrates may be introduced and new biotypes may be described by further sub-type designations.

D-Xylose and L-rhamnose proved useful in the differentiation of biotypes of S. typhimurium at both the primary and secondary levels (Duguid et al., 1975). The primary aim of this investigation, therefore, was to establish whether representatives of the series biotyped by Duguid et al. (1975) could be further discriminated into new sub-types by their reactions with the pentitols andfpentoses other than D-xylose or L-rhamnose.

\section{METHODS}

Bacteria. The I 20 strains of $S$. typhimurium examined were among those studied by Duguid et al. (1975) and represented 18 of the 19 known primary biotypes. Their single biotype 23 strain was not examined. The number of strains chosen from each biotype reflected approximately the size of the primary biotype groups of the larger series. The strains, isolated from 27 sources and 31 different countries, represented 66 different phage-types, 57 different full biotypes and I 9 different phage-type/biotype combinations. Stock cultures were maintained on Dorset's egg medium (Cruickshank et al., 1975).

Media and culture conditions. The basic minimal salts medium of Davis \& Mingioli (I950) was used. For auxotrophic strains, growth factors were added to the basal medium: amino acids were added at 10 $\mu \mathrm{g} \mathrm{ml}^{-1}$, nicotinamide at $0.6 \mu \mathrm{g} \mathrm{m}^{-1}$ and other growth factors at the concentrations recommended by Meynell \& Meynell (1965). Solutions of the carbohydrates, sterilized by filtration, were added to sterile basal medium to a final concentration of $0.3 \%(\mathrm{w} / \mathrm{v})$, and then dispensed in approx. $20 \mathrm{ml}$ portions in sterile plastic Petri dishes. The carbohydrates tested were: D-arabinose, D-ribose, D-xylose and L-rhamnose from BDH, and D-lyxose, L-arabinose, L-fucose, L-lyxose, L-xylose, D-arabitol, L-arabitol, ribitol (adonitol) and xylitol from Sigma; they were used without further purification. Bacteria from $24 \mathrm{~h}$ cultures on nutrient agar (Oxoid) were emulsified in saline $\left(0.85 \%\right.$ w/v) to give approx. $10^{\circ}$ bacteria $\mathrm{ml}^{-1}$ and were then inoculated on to the plates using a 12-pronged stainless-steel inoculator. The plates were incubated at $37^{\circ} \mathrm{C}$ and the presence or absence of growth was noted at 24 and $48 \mathrm{~h}$, and after 4 and 7 days; $48 \mathrm{~h}$ was chosen as the time for definitive reading.

Peptone water (Oxoid; $1.5 \%$, w/v), containing bromocresol purple $\left(20 \mu \mathrm{g} \mathrm{ml}^{-1}\right)$ and the test carbohydrate $(0.5 \%, \mathrm{w} / \mathrm{v})$, was dispensed in $5 \mathrm{ml}$ portions into $6 \mathrm{ml}$ bottles and inoculated with approx. $5 \times 10^{7}$ bacteria. The bottles were incubated at $37^{\circ} \mathrm{C}$ and examined for acid production (colour change from purple to yellow) at intervals during the first $48 \mathrm{~h}$ and then daily for 90 days. Strains were judged to be strong, weak or non-fermenters by the criteria of Duguid et al. (1975).

Phage-types. This information was supplied by Professor E. S. Anderson, Enteric Reference Laboratory, Central Public Health Laboratory, London. 
Table I. Ability of 120 wild-type Salmonella typhimurium strains from 18 primary biotypes to utilize pentoses and pentitols as carbon source

The primary biotypes (and number of strains in each biotype) tested were: $I(9), 2(5), 3(8)$, 4(I), 7(4), 9(4), 12(I), 17(20), 18(2), 19(5), 2I(I), 25(14), 26(13), 27(3), 29(3), 30(2), 3I(I8) and $32(7)$.

Sugars not utilized by any strain of any biotype:

Sugars utilized by all strains of all biotypes:

Sugars utilized by strains of some biotypes:

\author{
D-arabinose, D-lyxose, L-lyxose, L-xylose \\ D-arabitol, L-arabitol, ribitol, xylitol \\ L-arabinose, D-ribose, L-fucose \\ D-xylose by strains of biotypes I, 2, 3, 4, 7, \\ and 12 \\ L-rhamnose by strains of biotypes $I, 2,3,4$, \\ $17,18,19,25$ and 26
}

\section{RESULTS AND DISCUSSION}

Among the 2030 wild-type strains of $S$. typhimurium examined by Duguid et al. (I three distinct phenotypes - strong fermenters, weak fermenters and non-fermenters found on the basis of utilization of D-xylose and L-rhamnose. The strong ferme (Xyl+, 935 strains; $\mathrm{Rha}^{+}, \mathrm{I}_{677}$ strains) fermented $\mathrm{D}$-xylose or L-rhamnose in less Io $\mathrm{h}$ in peptone water and utilized these substrates as sole carbon sources in $\mathrm{Bi}$ medium (Bitter, Weigmann \& Habs, 1926) in $24 \mathrm{~h}$ and on minimal agar in $48 \mathrm{~h}$. V fermenters (Xylw, I083 strains; Rhaw 54 strains) fermented D-xylose or L-rhamno: peptone water in to to $24 \mathrm{~h}$ but not in Bitter's medium or on minimal agar. Non-ferme (Xyl-, I2 strains; Rha-, 299 strains) did not utilize these substrates in $48 \mathrm{~h}$ in any o media tested, but from cultures of every strain 'late' mutational fermentation was al observed after incubation for 2 to 40 days or more.

My results (Table I) agree with those of Duguid et al. (1975) for strains from bio I to 12 and strains from biotypes I, 2, 3, 4, 9, 17, I8, I9, 25 and 26 which used, respecti D-xylose and L-rhamnose as sole carbon source. Furthermore, it was confirmed strains from biotypes 17 to 32 and strains from biotypes 12 and 27 fermented, respecti $D$-xylose and L-rhamnose in 10 to $24 \mathrm{~h}$ in peptone water, although they were unab use them as sole carbon source. Of the other substrates, only D-ribose, L-arabinose L-fucose were utilized as sole carbon sources and they had no differentiating value ber they were used and fermented promptly by all strains regardless of biotype.

Although unable to utilize D-arabinose or L-lyxose as a sole carbon source, all st regardless of biotype fermented D-arabinose in 2 to 3 days and L-lyxose in 18 to From late-fermenting cultures, mutants were isolated that used these carbohydrat a sole carbon source, and fermented L-lyxose in $6 \mathrm{~h}$ or D-arabinose in 18 to $24 \mathrm{~h}$.

No other carbohydrate was used as sole carbon source by any wild-type strain, no continued incubation of the peptone water cultures for up to 90 days yield late (muts fermenters.

Other enterobacteria are more versatile in the use of these same substrates. Kleb pneumoniae strains, for example, possess inducible enzymes for the degradation of D-ri $\mathrm{D}$-xylose, L-arabinose, $\mathrm{D}$-arabitol and ribitol and readily produce mutants for growth $\mathrm{o}$ less common pentoses and pentitols such as D-arabinose, L-lyxose, L-xylose, L-ara and xylitol, converting them to intermediates in the degradative pathways of the na substrates (Mortlock \& Wood, 1964; Mortlock, 1976). However S. typhimurium st1 like Escherichia coli (Le Blanc, I970), are refractive to the pentoses and pentitols.

There is little information on the utilization of the pentoses and pentitols by S.typhimu and the results reported here are useful for they confirm and expand the results of $\mathrm{Gu}$ et al. (1969) who examined the single phage-type $S$. typhimurium strain LT-2 (Lillee] 1948) which belongs to biotype Idfj in the scheme of Duguid et al. (1975). My ri 
indicate that no extra biotype information would be gained by adding any other pentose or pentitol to the biotyping scheme of Duguid et al. (1975).

\section{REFERENCES}

BitTer, L., WeigmanN, F. \& HABs, H. (I926). Bestimmung der gebildeten Säuremenge zur Unterscheidung verwandter Bakterien. Rhamnosereaktion zur Differenzierung von Paratyphus-B und Breslaubakterien. Münchener medizinische Wochenschrift 73, 940-941.

Cruickshank, R., Duguid, J. P., Marmion, B. P. \& SwaIn, R. H. A. (1975). Medical Microbiology, vol. 2, The Practice of Medical Microbiology. Edinburgh, London and New York: Churchill Livingstone.

Davis, B. D. \& Mingioli, E. S. (1950). Mutants of Escherichia coli requiring methionine or vitamin $B_{12}$. Journal of Bacteriology 60, 17-28.

Duguid, J. P., Anderson, E. S., Alfredsson, G. A., BARKER, R. \& OLD, D. C. (1975). A new biotyping scheme for Salmonella typhimurium and its phylogenetic significance. Journal of Medical Microbiology 8, I49-166.

Gutnick, D., Calvo, J. M., Klopotowski, T. \& AmEs, B. N. (1969). Compounds which serve as the sole source of carbon or nitrogen for Salmonella typhimurium LT-2. Journal of Bacteriology roo, 215-219.

LE BlanC, D. J. (1970). Pathways of D-arabinose degradation among coliforms. Ph.D. thesis, University of Massachusetts, U.S.A.

LILlEENGEN, K. (1948). Typing of Salmonella typhimurium by means of bacteriophage. Acta pathologica et microbiologica scandinavica suppl. 77, I-I 25.

Meynell, G. G. \& Meynell, E. (1965). Theory and Practice in Experimental Bacteriology. Cambridge: Cambridge University Press.

MoRTLOCK, R. P. (1976). Catabolism of unnatural carbohydrates by microorganisms. Advances in Microbial Physiology 13, I-53.

Mortlock, R. P. \& WoOD, W. A. (1964). Metabolism of pentoses and pentitols by Aerobacter aerogenes. I. Demonstration of pentose isomerase, pentulokinase and pentitol dehydrogenase enzyme families. Journal of Bacteriology 88, 838-844. 